\title{
PENGEMBANGAN MEDIA PEMBELAJARAN BERBASIS POWER POINT ISPRING SUITE 8 DI SEKOLAH DASAR
}

Imam Nuraini $^{(1)}$, Sutama $^{(2)}$, Sabar Narimo
Universitas Muhammadiyah Surakarta
${ }^{(1)}(2)$

DOI: $10.23917 /$ varidika.v31vi2i.10220

\begin{abstract}
Submission
Track:

Received:

19 August 2019

Final Revision:

19 November 2019

Available online:

27 December 2019

Corresponding

\section{ABSTRACT}

The purpose of this research is to develop learning media using power point I Spring Suite 8 which are valid, practical and effective on the concept of the Central and Local Government Systems. The method used is development research with reference to the ADDIE development model which consists of 5 stages: analysis, design, development, implementation, and evaluation. The assessment instruments consisted of three, namely (1) validity instruments in the form of validity assessment tools of interactive learning media Power Point Ispring Suite 8 and validity assessment instruments questionnaire, (2) practicality instruments in the form of teacher responses and students' responses to learning media using Power Point Ispring Suite 8, and (3)

Author:

Name \& E-mail Address

Imam Nuraini ${ }^{(1)}$, Sutama ${ }^{(2)}$, Sabar Narimo ${ }^{(3)}$

Imnuai.86@gmail.com effectiveness instruments in the form of student learning outcomes. Based on data analysis, obtained an average of media validity is 4.15 (valid). Practicality of the media obtained $93.40 \%$ teacher response (very strong) and student responses of $91.40 \%$ (very strong). Learning Media has fulfilled the effectiveness criteria, namely $91 \%$ of students achieve mastery learning value. Based on the results of the study it can be concluded that the learning media based on Power Point Ispring Suite 8 on the concept of central and regional government that is developed is valid, practical, and effective.
\end{abstract}

Keywords: learning media, Power Point, Ispring Suite 8

\section{PENDAHULUAN}

Pendidikan merupakan sektor yang sangat menentukan kualitas suatu bangsa.Dunia pendidikan menuntut untuk dilakukannnya inovasi dan kreativitas yang dapat mendukung 
peningkatan mutu pendidikan. Perkembangan teknologi sejalan dengan peningkatan mutu pendidikan yang tertuang dalam Peraturan PemerintahRI Nomor 32 tahun 2013 perubahan atas Peraturan Pemerintah nomor 19 tahun 2005 pada bab 4 tentang Standar Nasional Pendidikan mengenai standar proses, menyatakan bahwa Proses pembelajaran pada satuan pendidikan diselenggarakan secara interaktif, inspiratif, menyenangkan, menantang, memotivasi peserta didik untuk berpartisipasi aktif, serta memberikan ruang yang cukup bagi prakarsa, kreativitas, dan kemandirian sesuai dengan bakat, minat, dan perkembangan fisik serta psikologis peserta didik.

Penggunaan media berfungsi sebagai alat perantara penyampaian materi pembelajaran agar dapat diterima peserta didik dengan lebih mudah dalam proses pembelajaran, serta membutuhkan penggunaan media yang tepat dan dapat menarik perhatian peserta didik. Penggunaan media pembelajaran dalam proses belajar mengajar dapat membangkitkan keinginan dan minat yang baru, serta membangkitkan motivasi belajar peserta didik.

Implementasi pembelajaran abad 21 tertuang dalam kurikulum 2013yang merupakan pembelajaran yang mengintegrasikan kemampuan literasi, kecakapan pengetahuan, keterampilan dan sikap serta penguasaan terhadap teknologi. Guru dituntut untuk mampu mengoperasikan teknologi sehingga proses pembelajaran menjadi lebih mudah, mempercepat, memperindah sehingga mampu meningkatkan minat belajar bagi pesertadidik.

Perkembangan teknologi yang begitu pesat, memberikan dampak positif dalam proses belajar mengajar. Setiap pengajar dituntut untuk menguasai teknologi agar dapat memberikan media pembelajaran yang menarik dan aktif bagi peserta didik.Hal ini tertuang pada Undangundang No.14 tahun 2005 bahwa guru berkewajiban meningkatkan dan mengembangkan kualifikasi akademik dan kompetensi secara berkelanjutan sejalan dengan perkembangan ilmu pengetahuan, teknologi danseni.

Media pembelajaran berbasis teknologi yang sering digunakan antara lain Adobe Flash, Construct,Android, power pointdan sebagainya, yang umum digunakan adalah Power Point. Salah satu media pembelajaran menggunkanPower Pointyang diinstal addinsIspring Suite 8 belum banyak dikembangkan. Ispringmerupakan salah satu tool yang dapat mengubah file presentasi yang kompatibel dengan power point untuk dijadikan dalam bentuk flash.

Penelitian yangdilakukandiSD Negeri Pucangan 04 Kecamatan Kartasuraberdasarkan hasil wawancara kepala sekolah dan guru kelas VI untuk nilai hasil belajar siswa tentang sistem pemerintahan pusat dan daerah masih di bawah kriteria ketuntasan minimal (KKM) yang ditetapkan. Dari jumlah siswa kelas VI sebanyak 23 siswa, hanya 8 siswa yang memperoleh nilai di atas KKM dengan rata-rata nilai 8,0 dan sebanyak 15 siswa di bawah nilai KKM dengan rata-rata nilai 5,4. Untuk KKM yang ditentukan yaitu 75.Ini membuktikan bahwasanya pembelajaran belum bisa maksimal.

Bertolak dari hasil wawancara tersebut, peneliti kemudian mengadakan observasi dan didapat hasil bahwasanya proses pembelajaran selama ini masih bersifat monoton dan tidak bervariasi. Proses pembelajaran tidak memperhatikan keaktifan peserta didik, sehingga terkadang peserta didik merasa bosan dan tidak ikut aktif berpartisipasi selama proses pembelajaran berlangsung, hal ini menunjukan bahwa pembelajaran tentang sistem pemerintah pusat dan daerah masih kurangefektif. 
Berdasarkan hal tersebut, maka peneliti membuat media pembelajaran menggunakan program komputer yaitu dengan pengembangan media pembelajaran berbasis power point denganaddinsIspring Suite 8 pada konsep pembelajaran sistem pemerintah pusat dan daerah

Penelitian yang dilakukan oleh Wijayanto, et al. (2017), mengatakan bahwa penggunaan multimedia interaktif yang digunakan sebagai metode pembelajaran dengan software Ispringdapat dijadikan sebagai variasi sarana pembelajaran untuk meningkatkan motivasi dan kreativitas peserta didik. Media yang digunakan membuat peserta didik menjadi aktif dalam proses pembelajaran. Selain itu dapat dijadikan sebagai bahan pembanding untuk mengembangkan media pembelajaran yang lebih baik.Media yang digunakan meningkatkan minat dan motivasi peserta didik.

Sedangkan penelitian yang dilakukan oleh Fazzlijan Mohamed Adnan Khan, Mona Masood (2012: 5666 - 5671) yang mengembangkan animasi dengan software Ispring Suite 8didapat hasil bahwasanya siswa dalam kelompok Animasi Narasi memperoleh tingkat pencapaian yang lebih tinggi secara signifikan dibandingkan dengan kelompok Narasi Teks.

Berdasarkan uraian tersebut, tujuan penelitian ini mengembangkan media pembelajaran menggunakan power point ISpring Suite 8 yang bersifat valid, praktis dan efektif pada konsep Sistem Pemerintah Pusat dan Daerah.

\section{METODE}

Penelitian yang digunakan adalah penelitian pengembangan atau Research and Development $(\mathrm{R} \& \mathrm{D})$. Model pengembangan yang digunakan adalah model ADDIE, terdiri dari 5 tahap, yaitu analyze (analisis), design (desain), development (pengembangan), implementation (implementasi) dan evaluation (evaluasi). Media pembelajaran yang dikembangkan adalah berupa (1) Media pembelajaran berbasis power point tentang sistem pemerintah pusat dan daerah, (2) terintegrasi dengan sejumlah video, animasi, dan kuis, (3) Software yang digunakan adalah Power Point addins Ispring Suite 8.

Teknik pengumpulan data yang digunakan dalam penelitian dan pengembangan ini yaitu observasi, wawancara guru mata pelajaran, angket dan tes hasil belajar. Instrumen yang digunakan dalam penelitian ini, berupa lembar evaluasi hasil tes belajar peserta didik dan angket yang terdiri dari: 1) angket validasi yang diberikan kepada validator untuk mengukur kevalidan media, 2) angket respon peserta didik, 3) angket respon guru, dan lembar evaluasi digunakan untuk melihat keefektifan media pembelajaran menggunakan Power Point Ispring Suite 8 .

Data yang diperoleh dengan menggunakan instrumen yang dikembangkan selanjutnya dianalisis secara deskriptif kuantitatif.

\section{Analisis data kevalidan}

Kegiatan yang dilakukan dalam proses analisis data kevalidan perangkat pembelajaran adalah sebagai berikut (Hobri, 2009):

$$
\begin{aligned}
& 1 \leq \text { va }<2 \text { tidak valid } \\
& 2 \leq \text { va }<3 \text { kurang valid } \\
& 3 \leq \text { va }<4 \text { cukupvalid } \\
& 4 \leq \text { va }<5 \text { valid } \\
& \text { va }=5 \text { sangat valid }
\end{aligned}
$$


Terkait dengan validitas pada penelitian dan pengembangan yang ingin dicapai yaitu kriteria valid dan minimal tingkat validitas yang dicapai adalah kategori valid $4 \leq$ va $<5$. Apabila validasi dibawah kategori maka dilakukan koreksi sampai diperoleh media yang ideal dari ukuran validitas media dan materi.

\section{Analisis data kepraktisan}

Analisis terhadap kepraktisan media pembelajaran menggunakan data respon guru dan peserta didik, yaitu sebagai berikut:

1) Mencocokkan persentase rata-rata nilai respon dengan kategori respon menurut Riduwan (2010) yaitu sebagaiberikut:

a) $80 \% \leq \bar{R} \leq 100 \%$ : dikategorikan sangatkuat

b) $60 \% \leq \bar{R}<80 \%$ : dikategorikan kuat

c) $40 \% \leq \bar{R}<60 \%$ : dikategorikan cukup kuat

d) $20 \% \leq \bar{R}<40 \%$ : dikategorikan lemah

e) $0 \% \leq \bar{R}<20 \%$ : dikategorikan sangat lemah

2) Menghitung banyaknya kategori sangat kuat, kuat, cukup kuat, lemah dan sangat lemah dari seluruh pernyataan. Selanjutnya mencocokkan dengan kategori menurut Riduwan (2010), yaitu sebagai berikut:

a) Jika $\geq 50 \%$ dari seluruh pernyataan termasuk dalam kategori sangat kuat dan kuat, maka respon dikatakan positif.

b) Jika $<50 \%$ dari seluruh pernyataan termasuk dalam kategori sangat kuat dan kuat, maka respon dikatakannegatif.

Adapun untuk penentuan praktis atau tidaknya media dapat dilihat dari hasil akhirnya.Jika hasil akhirnya dinyatakan bahwa respon guru atau peserta didik terhadap media tersebut dikategorikan positif, maka dapat dinyatakan praktis.

\section{Analisis data keefektifan}

Analisis terhadap keefektifan media pembelajaran menggunakan data tes hasil belajar dengan mengacu pada pedoman penilaian menurut (Hobri, 2009) yaitu sebagai berikut.

a. Skor 85-100 : dikategorikan sangat tinggi.

b. Skor $65-84$ : dikategorikan tinggi.

c. Skor 55-64 : dikategorikan sedang.

d. Skor 35 - 54 : dikategorikan rendah.

e. Skor $0-34$ : dikategorikan sangat rendah.

Ketuntasan tes hasil belajar peserta didik berdasarkan pada Kriteria Ketuntasan Minimum (KKM) yang telah ditetapkan oleh pihak sekolah.Seorang peserta didik dikatakan berhasil dalam belajar jika memperoleh nilai minimal 75.Pembelajaran dikatakan berhasil secara klasikal jika minimal 70\% peserta didik mencapai skor minimal 75 (tinggi).

\section{HASIL PENELITIAN}

Media pembelajaran yang dikembangkan adalah berupa (1) Media pembelajaran berbasis power point tentang sistem pemerintah pusat dan daerah, (2) terintegrasi dengan 
sejumlah, animasi, permainan dan kuis, (3) Software yang digunakan adalah Power Point dengan addinsIspring Suite 8. Berikut ini tampilan menu utama media pembelajaran yang telah dikembangkan:

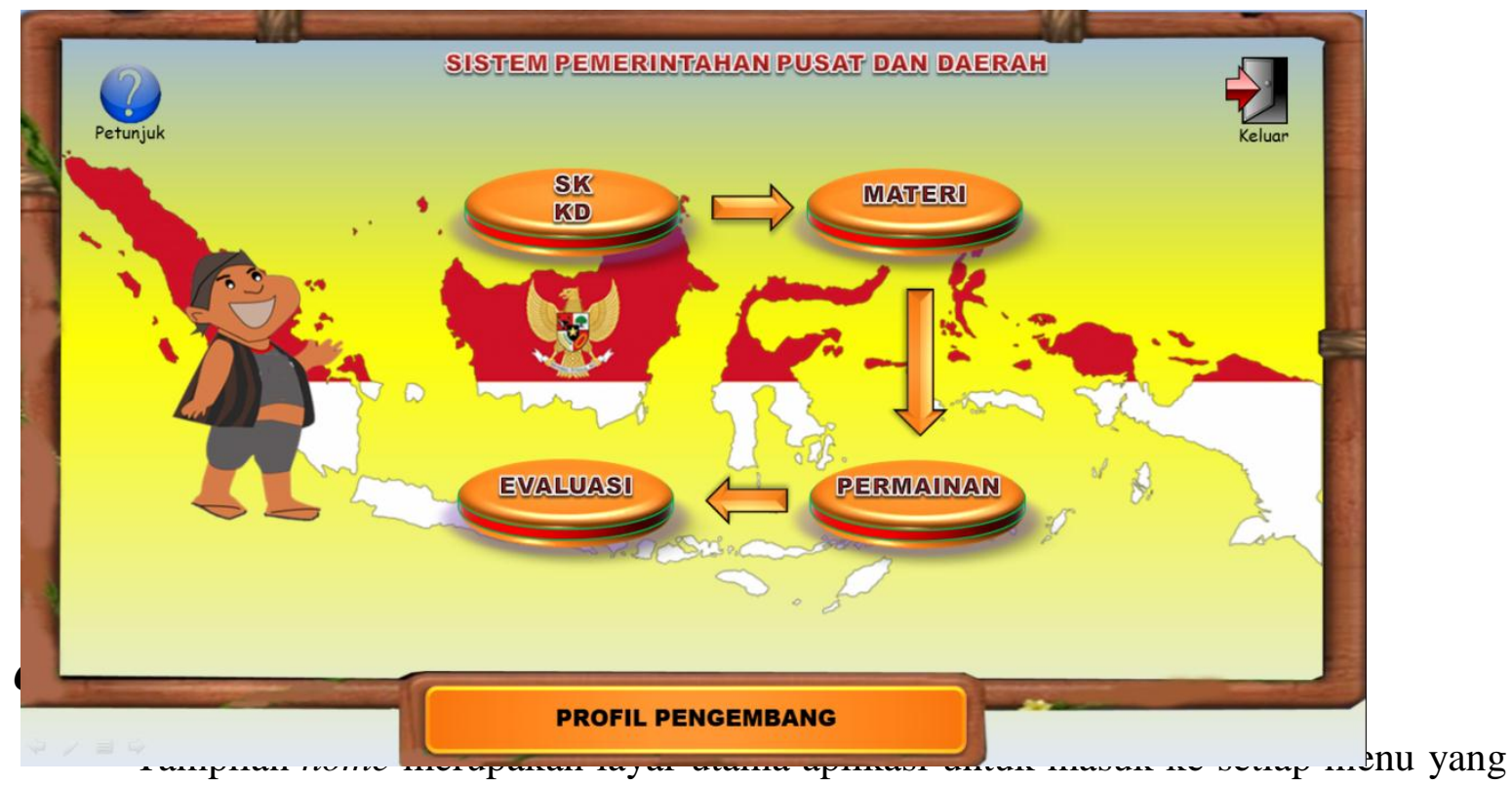

diinginkan. Berikut adalah hasil analisis data kevalidan, kepraktisan, dan keefektifan media pembelajaran interaktif Power Point Ispring Suite 8.

\section{a. Kevalidan}

Validitas diukur menggunakan instrument validasi media pembelajaran interaktif yang dibuat oleh peneliti dan diberikan kepada validator ahli untuk memvalidasi media pembelajaran menggunakanPower Point Ispring Suite 8.

Uji validitas untuk melihat kekurangan media pembelajaran interaktif Power Point Ispring Suite 8 baik dari segi konten maupun dari tampilan (layout).

Tabel 1 Hasil Analisis Kevalidan Media Pembelajaran Power Point Ispring Suite 8 pada konsep pemerintahan pusat dan daerah

\begin{tabular}{llllll}
\hline No & Aspek Penilaian & $\begin{array}{l}\text { Rata-rata } \\
\text { Skor }\end{array}$ & & Va & Ket \\
\cline { 3 - 4 } & & Va1 & Va2 & & \\
\hline 1 & Kompetensi dasar & 5.0 & 5.0 & 5.0 & Sangat Valid \\
2 & Isi/Konten & 4.0 & 4.0 & 4.0 & Valid \\
3 & Konsep & 4.0 & 4.0 & 4.0 & Valid \\
& $\begin{array}{l}\text { pembelajaran } \\
4\end{array}$ & & & & \\
& Pengorganisasian & 4.5 & 4.0 & 4.2 & Valid \\
5 & materi & & & & \\
6 & Konsep teknis & 4.0 & 4.0 & 4.0 & Valid \\
& Konsep media & 4.0 & 4.0 & 4.0 & Valid
\end{tabular}




\begin{tabular}{llllll}
7 & Konsep komunikasi & 4.0 & 4.0 & 4.0 & Valid \\
8 & Tes dan evaluasi & 4.0 & 4.0 & 4.0 & Valid \\
\hline Rata-rata & & & 4.15 & Valid \\
\hline
\end{tabular}

Ket:

Va1 = validator 1

$\mathrm{Va} 2$ = validator 2

Berdasarkan hasil analisis yang di tunjukkan pada tabel 1 diperoleh nilai rata-rata total kevalidan keseluruhan media pembelajaran interaktif Power Point Ispring Suite 8 yang digunakan dalam mendukung proses pembelajaran diperoleh va adalah 4.15, dapat disimpulkan bahwa nilai tersebut termasuk dalam kategori "valid" $(4 \leq \mathrm{va}<5)$.

\section{b. Kepraktisan Media Pembelajaran Power Point Ispring Suite8}

Uji kepraktisan media dilihat berdasarkan respon guru dan respon peserta didik

1) Kepraktisan produk berdasarkan respon peserta didik

Berdasarkan data respon peserta didik terhadap media pembelajaran interaktif Power Point Ispring Suite 8, ada 15 pernyataan yang terdiri dari respon positif dan respon negative peserta didik setelah menggunakan media pembelajaran Power Point Ispring Suite 8 , menunjukkan rata-rata yang diperoleh adalah " 4.57 " dengan persentase $91,40 \%$ dengan kategori sangat kuat (di atas 80\%). Hal ini menunjukkan bahwa respon peserta didik terhadap penggunaan media pembelajaran interaktif Power Point Ispring Suite 8 memperoleh respon positif oleh peserta didik.

2) Kepraktisan Produk berdasarkan responguru

Berdasarkan data respon guru yang diperoleh melalui angket respon positif dan respon negatif dari guru kelas VI diperoleh nilai rata-rata sebesar "4.67" dengan rata-rata persentase $93.40 \%$ menunjukkan bahwa guru kelas VI memberikan respon positif terhadap media pembelajaran menggunakanPower Point Ispring Suite 8 yang berada pada kategori “ sangat kuat".

c. Kefeektifan Media Pembelajaran Power Point Ispring Suite 8

d.

Tabel 2 Distribusi Frekuensi Persentase Hasil Belajar Peserta Didik Kelas VI SD Negeri Pucangan 04 pada konsep Sistem Pemerintah Pusat dan Daerah

\begin{tabular}{llllc}
\hline No & Interval & Kategori & Frekuensi & Persentase \\
\hline 1 & $85-100$ & Sangat tinggi & 18 & 78.26 \\
2 & $65-84$ & Tinggi & 3 & 13.04 \\
3 & $55-64$ & Sedang & 2 & 8.70 \\
4 & $35-54$ & Rendah & - & - \\
5 & $0-34$ & Sangat Rendah & - & - \\
\hline & Jumlah & & 23 & 100 \\
\hline
\end{tabular}


Berdasarkan hasil analisis data statistik hasil belajar peserta didik, sebanyak 23 orang yaitu $91,3 \%$ peserta didik yang mencapai KKM atau dapat dikatakan tuntas. Nilai KKM mengacu pada KKM yang di tetapkandiSD Negeri Pucangan 04 kecamatan Kartasura. Frekuensi persentase hasil belajar menunjukkan 78,26\% peserta didik memperoleh nilai diatas 85, sehingga hal ini menunjukkan bahwa media pembelajaran interaktif Power Point Ispring Suite 8 yang telah dikembangkan dapat dikatakan efektif.

\section{PEMBAHASAN}

\section{a. Kevalidan Media Pembelajaran Power Point Ispring Suite 8}

Berdasarkan hasil yang diperoleh dari analisis data nilai kevalidan media pembelajaran oleh kedua validator yaitu sebesar "4.15" yang berada kategori "valid"( $4 \leq \mathrm{Va}<5)$. Berdasarkan nilai total kevalidan maka media pembelajaran berbasisPower Point Ispring Suite 8 layak untuk digunakan kepada subjek penelitian. Nilai valid yang diperoleh dengan ketercapaian indikator penilaian berupa kesesuaian penyajian materi pembelajaran dengan indikator pencapaian kompetensi, dukungan media terhadap penanaman konsep, kesesuaian materi pembelajaran dengan tujuan pembelajaran, kebenaran uraian materi pembelajaran, urutan penyajian materi pembelajaran, kesesuaian gambar dan animasi dengan uraian materi pembelajaran, kesesuaian soal-soal latihan dengan tujuan pembelajaran, dan kejelasan uraian materi pembelajaran. Perangkat pembelajaran dikatakan valid jika penilaian ahli menunjukkan bahwa pengembangan perangkat tersebut memiliki konsistensi internal antara setiap aspek yang dinilai yakni keterkaitan antara komponen dalam perangkat pembelajaran (Mustami, 2015). Lebih lanjut dikemukakan oleh Hala (2015), bahwa Jika keseluruhan aspek penilaian telah mencapai kriteria kevalidan, maka media yang dikembangkan dinyatakan layak digunakan dalam pembelajaran.

\section{b. Kepraktisan Media Pembelajaran Power Point Ispring Suite 8}

Berdasarkan data yang diperoleh, pembelajaran dengan media pembelajaran berbasis Power Point Ispring Suite 8 memiliki nilai kepraktisan yang baik. Hasil respon guru menunjukkan nilai rata-rata respon di angka 4.67 dengan presentase 93,40 \% dengan kategori sangat kuat, hasil respon peserta didik 4.57 dengan presentase $91.40 \%$ dengan kategori sangat kuat.

Penelitan pengembangan yang dilakukan oleh Rafiq, et al. (2017) terhadap pengembangan media pembelajaran Power Point \& Ispring Suite di SMP Negeri 1 Kota Jambi bahwa media tersebut dapat digunakan oleh peserta didik secara mandiri dirumah dan dimanapun. Media pembelajaran yang dikembangkan menurut pandangan peserta didik sudah sangat baik sehingga dapat menarik minat dan motivasi peserta didik dalam proses kegiatan pembelajaran. Hasil penelitian yang dilakukan oleh Wijayanto, et al. (2017) bahwa dengan pemanfaatan media pembelajaran Ispring Suite 8 mampu meningkatkan motivasi dan hasil belajar peserta didik serta memberikan kontribusi pada pembelajaran interaktif dan dinamis.

\section{c. Keefektifan Media Pembelajaran Power Point Ispring Suite 8}

Keefektifan media pembelajaran dinilai dari penilaian hasil belajar peserta didik. Jumlah peserta didik yang dinyatakan tuntas yaitu peserta didik yang mencapai standar ketuntasan minimal (75) sebanyak 21 peserta didik atau 91\%. Sementara sebanyak 2 orang peserta didik yang tidak mencapai KKM atau dapat dikatakan tidak tuntas. Dapat dikatakan bahwa media yang dikembangkan termasuk dalam kategori efektif. Media pembelajaran dapat dikatakan efektif jika $70 \%$ peserta didik yang telah mengikuti proses pembelajaran mampu mencapai nilai ketuntasan minimal yang telah ditetapkan (Hobri,2009). 
Pembelajaran dikatakan berhasil secara klasikal jika minimal $70 \%$ peserta mencapai nilai tuntas.Hal ini menunjukkan bahwa media pembelajaran yang dikembangkan telahefektif.

Hasil belajar peserta didik adalah hasil dari berbagai upaya dan daya yang tercermin dari partisipasi belajar yang dilakukan peserta didik dalam mempelajari materi pembelajaran (Saleh, et al. 2015). Terciptanya proses pembelajaran yang mampu meningkatkan belajar beripikir peserta didik tentunya sangat dipengaruhi oleh motivasi belajar peserta didik. Pemanfaatan media pembelajaran yang baru dalam proses pembelajaran dapat meningkatkan motivasi belajar peserta didik yang tentunya akan berdampak pada hasil belajar peserta didik. Motivasi yang baik pada peserta didik mampu menciptakan suasana belajar yang nyaman sehingga tujuan pembelajaran dapat tercapai.Motivasi merupakan kunci uatama kesuksesan dalam akademik (Sanacore,2008).

Penelitian yang dilakukan oleh Cimer\&Atilla (2012), menyatakan bahwa peserta didik dapat mengingat dengan baik mengenai ide dan konsep yang ditampilkan dengan melibatkan sensori peserta didik, misalnya penyajian materi secara audio dan visual, gambar, carta, model dan multimedia. Mengajar dengan menggunakan media yang bersifat visual dapat memberikan makna konkrit terhadap suatu kata/istilah, memperlihatkan kaitan dan hubungan ide-ide secara eksplisit, dan gambar yang mudah tersimpan dalam ingatan peserta didik dan membuat pembelajaran lebih menarik.

Pemanfaatan teknologi dalam penyediaan media pembelajaran tentunya sangat mendukung dalam proses pembelajaran terutama media pembelajaran yang interaktif. Media pembelajaran interaktif merupakan media penyampaian pesan antara tenaga pendidik kepada peserta didik yang memungkinkan komunikasi antara manusia dan teknologi melalui sistem dan infrastruktur berupa program aplikasi serta pemanfaatan media elektronik sebagai bagian dari metode edukasinya, melalui media pembelajaran interaktif proses belajar dapat dilakukan dimana saja dan kapan saja (Sasahan, etal .2017). Microsoft Power Point mampu menampilkan program multimedia menarik dengan tampilannya yang dapat berupa teks, gambar, dan video (Daryanto,2013). Penggunaan Ispringsuite dengan penyajian yang menarik dapat meningkatkan motivasi belajar peserta didik. Media yang komunikatif dapat menyajikan informasi materi atau konsep yang ada pada media sebagai sumber pesan kepada peserta didik sehingga mampu meningkatkan hasil belajar peserta didik (Himmah\& Martini, 2017).

\section{KESIMPULAN}

Pengembangan media pembelajaran berbasis power point ispring suite 8 mengacu pada model pengembangan ADDIE terdiri dari 5 tahap, yaitu analyze (analisis), design (desain), development (pengembangan), implementation (implementasi) dan evaluation (evaluasi). Media pembelajaran berbasis Power Point Ispring Suite 8 yang dikembangkan bersifat valid, praktis, dan efektif. 


\section{DAFTAR PUSTAKA}

Adnan K., F. M., Mona M. 2012. Effectiveness of visual animation-narration presentation on student"s achievement in the learning of meiosis. International Jurnal Procedia Social and Behavioral Sciences 46 (2015) 5666 - 5671. Available online at www.sciencedirect.com

Cimer\&Atilla. 2012. What makes biology learning difficult and effective: Students' views.Educational Research and Reviews, (Online), Vol. 7, No. 3 (https://eric.ed.gov/?id=EJ972777,

Daryanto, 2013.Media Pembelajaran Peranannya sangat Penting dalam rangka mencapai Tujuan Pembelajaran. Yogyakarta

Hala, Y., Saenab, S., \& Kasim, S. 2015. Pengembangan Perangkat Pembelajaran Biologi Berbasis Pendekatan Saintifik pada Konsep Ekosistem Bagi Siswa Sekolah Menengah Pertama. Journal of EST, (Online), Vol. 1, No. 3 (http://ojs.unm.ac.id/JEST/article/view/1825, Diakses 10 Agustus 2019)

Hobri.2009. Metodologi Penelitian dan Pengembangan (Development and Reseacrh) (Aplikasi Pada Penelitian Pendidikan Matematika).Jember : FKIP Universitas Jember.

Saleh, H. I., Nurhayati, Jumadi O. 2015. Pengaruh Penggunaan Media Alat Peraga Terhadap Hasil Belajar Siswa pada Materi Sistem Peredaran Darah Kelas VIII SMP Negeri 2 Bulukumba.Jurnal Sainsmat, (Online), Vol.IV, No. 1 (7-13) ISSN2 086-6755 ( http :// ojs. unm. ac.id/ sainsmat/article/view/1280, Diakses 10 September 2019).

Mustami,M.K.\&Dirawan,G.D.2015.DevelopmentofWorksheetStudentsOrientedScientificApp roach at Subject of Biology. Man In India, (Online), Vol. 95, No. 4. (http://journals.com/serialjournalmanager/pdf/1456920315.pdf,_Diakses 10 September 2019).

Peraturan Pemerintah No. 32 Tahun 2013 tentang perubahan Peraturan Pemerintah No. 19 Tahun 2005 Tentang Standar Nasional Pendidikan.

Rafiq M., Sabil H, \&Ramalisa, 2017.Pengembangan Media Pembelajaran Berbasis Pendekatan Saintifik dengan Power Point \&Ispring Suite pada Materi Perbandingan di Kelas VIII SMP Negeri 1.Skripsi.Tidak diterbitkan. Jambi: Pendidikan Matematika. Universitas Jambi.

Riduwan, 2010.Skala Pengukuran Variabel-Variabel Penelitian. Bandung: Alfabeta.

Sanacore, J. 2008. Turning Reluctant Learners into Inspired Learners. Clearing House:A Journal of Educational Strategies, Issues and Ideas, (Online), Vol.82, No. 1. (https://eric.ed.gov/?id=EJ811947, Diakses 15 Januari2018).

Sasahan, E. Y., Oktova R. \&Oktavia O., 2017.Pengembangan Media Pembelajaran Interaktif tentang Optika Berbasis Android Menggunakan Perangkat Lunak Ispring Suite 7.0 untuk Mahasiswa S-1 Pendidikan Fisika pada Pokok Bahasan Interferensi Cahaya.Prosiding SNFA.E ISSN 2548- 8325/P-ISSN (2548-8317).

Undang-Undang No14.Tahun 2005. Tentang Guru dan Dosen. Bandung : Citra Umbara. 
Wijayanto P. A., Utaya S. \&Astina I, K. 2017. Increasing Student's Motivation and Geography Learning Outcome Using Active Debate Methode Assisted by Ispring Suite.International Journal of Social Sciences and Management, (Online), Vol. 4, No. 4.(https: //www .nepjol.info/index.php/IJSSM/article/view/18336, Diakses 12 September 2019). 